\title{
Colostral proteins from cows immunised with Streptococcus mutans/S. sobrinus support the phagocytosis and killing of mutans streptococci by human leucocytes
}

\author{
V. LOIMARANTA, J. NUUTILA*, P. MARNILA $\dagger$, J. TENOVUO, H. KORHONEN† and E.-M. LILIUS* \\ Institute of Dentistry and Turku Immunology Centre, *Department of Biochemistry, University of Turku, FIN- \\ 20520 Turku, Finland and †Agricultural Research Centre of Finland, Food Research Institute, FIN-31600 \\ Jokioinen, Finland
}

\begin{abstract}
Passive immunisation, based on bovine colostral preparations, is an area of active research. Specific bovine antibodies inhibit the virulence factors of target pathogens but the interactions between whey preparations and human immune defence cells are not well known. Bovine colostrum inhibits the phagocytic activity of bovine leucocytes and this may reflect the biological activity of immunoglobulins in it. Therefore, this study aimed to examine the effects of bovine whey protein preparations from the colostrum of Streptococcus mutans $/ S$. sobrinus-immunised and sham-immunised cows on binding, ingestion and killing of these bacteria by human leucocytes. Binding and ingestion of FITC-labelled bacteria were estimated by flow cytometry and leukocyte activation was measured as chemiluminescence. Killing rate was estimated by plate counting and by measuring bioluminescence from $S$. mutans- containing the insect luciferase gene. Colostral whey protein preparation from hyperimmunised cows activated human leucocytes by opsonising specific bacteria. Neutrophils, eosinophils and monocytes weakly phagocytosed non-opsonised bacteria and bacteria opsonised with control product. On the contrary, binding and ingestion were efficient in the presence of the preparation from immunised cows. Thus, these results show that bovine colostral whey proteins are able to support the activation of human phagocytes against pathogenic microbes and that this property is related to specific antibodies in whey preparations. These whey proteins may also be clinically useful, especially in preventing the colonisation of newly erupted teeth by mutans streptococci.
\end{abstract}

\section{Introduction}

Dental caries is one of the most common bacterial infectious diseases in the world. The microbial etiology of caries is primarily associated with the group of bacteria called mutans streptococci and especially the species Streptococcus mutans and S. sobrinus [1]. Because some anti-streptococcal antibodies can cross react with human tissues [2], immunological protection against these bacteria is not feasible by direct vaccination with whole cells as antigens; therefore, other approaches are being studied extensively. One proposed approach is passive immunisation in which pre-formed antibodies are transferred to the oral cavity.

Received 3 Nov. 1998; revised version accepted 23 Feb. 1999.

Corresponding author: Dr V. Loimaranta (e-mail. vuoloi@ utu.fi).
Studies have been done with monoclonal antibodies $[3,4]$ and with antibodies produced in common foodstuffs such as hen's egg-yolk $[5,6]$ and bovine milk $[7,8]$. Similarly, specific antibodies induced in bovine colostrum are used in passive immunisation against several other infectious diseases [9]. Generally, passive immunisation has had better effect in prevention than in treatment of a disease.

Recently, a new membrane separation and chromatographic technique has been applied to enrich the immunoglobulin-containing protein fraction from the colostrum of cows immunised with $S$. mutans $/ S$. sobrinus [10]. The concentrated whey proteins from the colostrum inhibited virulence factors of the oral streptococci in vitro $[10,11]$. However, their effects on the activity of human immunological defence factors, such as leucocytes, are not known. Bovine colostral whey proteins inhibit the functions of bovine neutro- 
phils [12] but only very sparse information is available on the effects of bovine immunoglobulins or other milk proteins on the action of human phagocytes [13]. Large numbers of leucocytes are constantly migrating from blood to gingival crevicular fluid and into the oral cavity. Gingival crevicular polymorphonuclear leucocytes (PMNLs) retain their viability and phagocytic [14] and chemotactic properties [15]. Saliva can increase the activity of crevicular PMNLs in vitro which may enhance the defence role of PMNLs in vivo as they enter the oral cavity [16]. Especially high numbers of leucocytes can be expected to be present around teeth during their eruption, which is the time when the cariogenic bacteria are established in the oral cavity [17]. Thus, even though $\mathrm{F}\left(\mathrm{ab}^{\prime}\right)_{2}$ fragments of the antibodies are effective in preventing the colonisation of $S$. mutans in adults [18], phagocytosis may be important in modifying the early colonisation of bacteria on tooth surfaces. Therefore, the aim of this study was to examine whether bovine colostral protein preparations from $S$. mutans $/ S$. sobrinus-immunised cows affect phagocytic activity of human leucocytes, and if these effects are related to the specific antibodies in the preparation.

\section{Materials and methods}

\section{Production of immune and control colostrum preparations}

The production and composition of whey proteins containing specific anti-S. mutans $/ S$. sobrinus antibodies from bovine colostrum was described in detail in our previous study [10]. Briefly, two pregnant Friesian cows were immunised intramuscularly with an $S$. mutans ATCC 25175 (serotype c) $/ S$. sobrinus ATCC 33478 (serotype d) $(1: 1)$ vaccine with $\mathrm{Al}(\mathrm{OH})_{3}$ as the adjuvant. A control cow was inoculated only with the adjuvant in saline. After the immunisation regimen and calving, the colostrum was collected. Colostral whey protein preparations were made by removing casein, fat, sugars and salts by centrifugation and chromatographic and membrane techniques. The final protein contents were $61 \%$ for the immune product (IP) and $73 \%$ for the control product (CP). In both cases, major protein components were immunoglobulins ( $37 \%$ in IP and $40 \%$ in CP) of which $\mathrm{IgG}_{1}$ comprised $>80 \%$ [10]. IP and CP also contained $\alpha$-lactalbumin (4\%) and $\beta$-lactoglobulin $(13 \%$ and $18 \%$, respectively). The specific IgG activities $\left(1000 \times \mathrm{A}_{405}\right.$; at a dilution of 1 in 300$)$ of IP determined by ELISA were 262 for $S$. mutans, and 517 for $S$. sobrinus. CP showed no specific activities for either $S$. mutans or $S$. sobrinus [10].

\section{Isolation of leucocytes}

Peripheral, ethylenediaminetetraacetic acid (EDTA)anticoagulated blood samples were collected from healthy volunteers. Blood erythrocytes were lysed with ammonium chloride (blood $1.5 \mathrm{ml}$, ammonium chloride $0.83 \%$ solution $8.5 \mathrm{ml}$ ) at room temperature for $15 \mathrm{~min}$. After lysis, the leucocytes were separated by centrifugation $(400 \mathrm{~g}, 10 \mathrm{~min})$ and resuspended in $\mathrm{Ca}^{2+}-$ and $\mathrm{Mg}^{2+}$-free Hank's Balanced Salt Solution with $0.1 \%$ (gel-HBSS).

\section{Opsonisation and labelling of bacteria}

Late log-phase S. mutans ATCC 25175 or S. sobrinus ATCC 33478 cells, grown in brain heart infusion broth (BHI; Difco, Detroit, MI, USA) at $37^{\circ} \mathrm{C}$, were washed five times with sterile saline and the $\mathrm{OD}_{620}$ was adjusted to $0.70\left(c .1 \times 10^{9} \mathrm{cfu} / \mathrm{ml}\right)$. The cells $(1 \mathrm{ml})$ were then harvested and $1 \mathrm{ml}$ of IP or CP in Trisbuffered saline (TBS, pH 7.2 ) in different concentrations $(0,0.1,0.5,1,5$ and $50 \mathrm{mg} / \mathrm{ml})$ was added and incubated with bacteria for $25 \mathrm{~min}$ at $37^{\circ} \mathrm{C}$. After washing three times with cold TBS, fluorescein isothiocyanate (FITC; Sigma) in $0.01 \mathrm{mg}$ in $1 \mathrm{ml}$ of $0.1 \mathrm{M} \mathrm{NaHCO}_{3}$ buffer ( $\left.\mathrm{pH} 9.6\right)$ was added and the cell suspension was incubated for $30 \mathrm{~min}$ at $37^{\circ} \mathrm{C}$. The cells were then washed with gel-HBSS and finally suspended in the same buffer. The treatment sequence (opsonisation before FITC versus FITC before opsonisation) was tested and found not to have any effect on the fluorescence intensity or the phagocytosis of the bacteria. The opsonised and labelled bacteria were stored at $-20^{\circ} \mathrm{C}$ until used. For the chemiluminescence assays, portions of the bacteria were stored without FITC treatment.

\section{Phagocytosis}

The effect of different concentrations of IP or CP on the opsonisation of mutans streptococci for phagocytosis by human leucocytes was examined by flow cytometry. The non-fractionated leucocytes (c. $3.0 \times$ $10^{5}$ ) and slightly sonicated (10 s, amplitude 5; MSE Disintegrator, London UK) non-opsonised or opsonised, FITC-labelled bacteria $\left(1.5 \times 10^{7}\right)$ were incubated in $0.5 \mathrm{ml}$ of gel-HBSS at $37^{\circ} \mathrm{C}$. Samples were withdrawn after 5, 15, 30, 45 and $60 \mathrm{~min}$ and immediately placed on ice. Phagocytosis was followed in neutrophils, eosinophils, monocytes and lymphocytes by gating each subpopulation according to forward scatter/side scatter histogram. Eosinophils were gated from the neutrophil population by using light-scattering polarisation [19].

Phagocytosis was determined from the fluorescence histogram where the gate $M 1$, fluorescence-positive leucocytes, was set by leaving fluorescence-negative leucocytes ( $98 \%$ of leucocytes) in the absence of labelled bacteria at the left side of the gate (Fig. 1a). For phagocytosis calculations, two parameters, the mean fluorescence intensity (MFI) and the percentage of fluorescence-positive cells, were obtained from gate M1. 

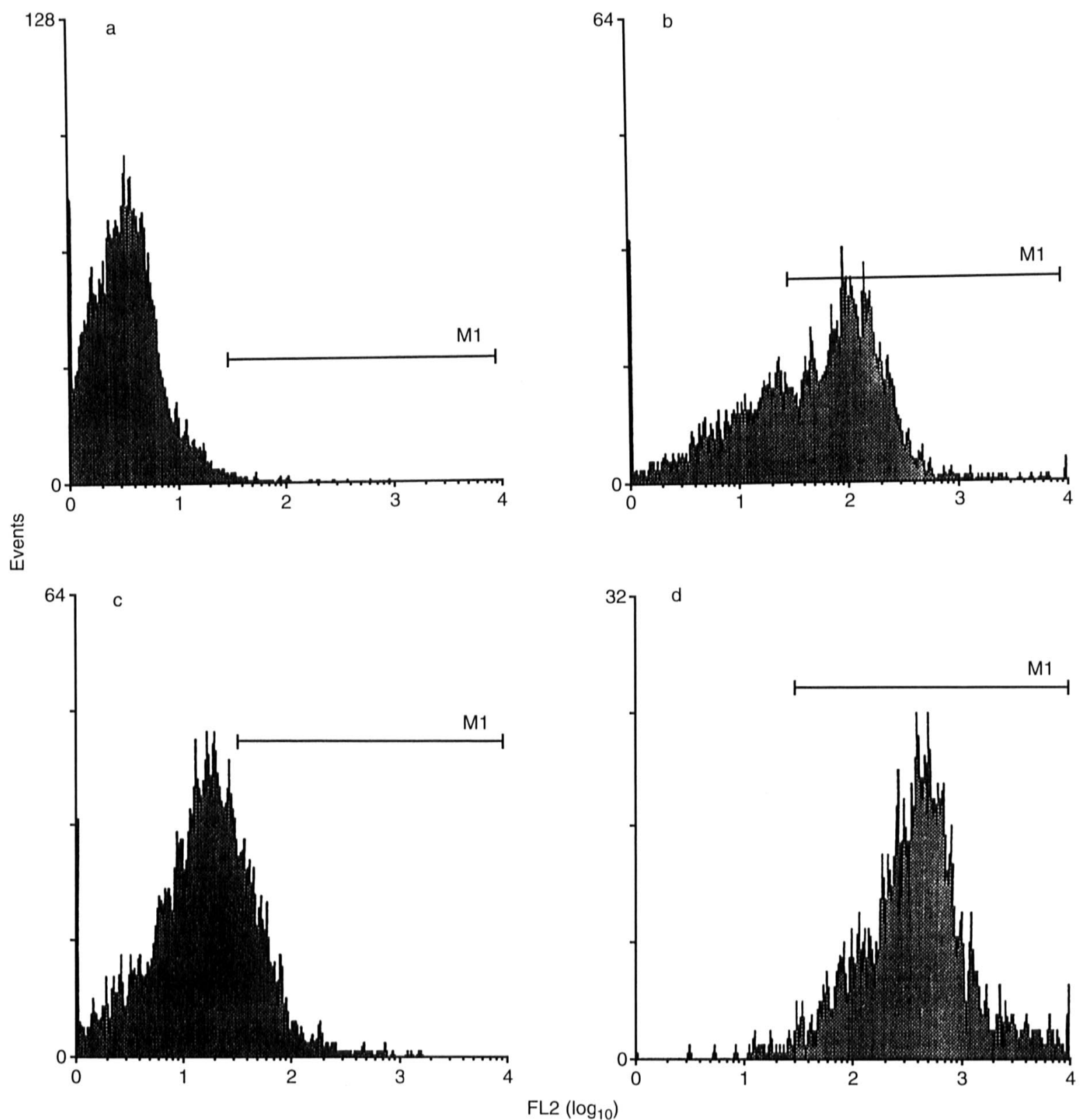

Fig. 1. Flow cytometry fluorescence histograms of $S$. mutans phagocytosis. (a) Background fluorescence of nonphagocytosing neutrophils; M1 is the gate for fluorescence-positive cells containing bound or ingested bacteria (b). Neutrophils incubated for $60 \mathrm{~min}$ at $37^{\circ} \mathrm{C}$ in the presence of non-opsonised $S$. mutans before and (c) after quenching with trypan blue. (d) Neutrophils incubated for $60 \mathrm{~min}$ at $37^{\circ} \mathrm{C}$ in the presence of $S$. mutans opsonised by immune product $(5 \mathrm{mg} / \mathrm{ml})$ after quenching.

MFI consists of the fluorescence of the bacteria both inside and on the surface of the leucocytes. Trypan blue (TB) quenches the fluorescence of bacteria on the surface but not those inside leucocytes [20]. The quenching capacity of TB was determined by using Raji-cells [21] and neutrophils in the presence of $10 \mathrm{nM}$ cytochalasin D [22]; both cause adherence of FITClabelled opsonised target particles on the cell surface without phagocytosis. The maximum quenching capacity was achieved with $\mathrm{TB}$ at $5 \mathrm{mg} / \mathrm{ml}$. It should be noted that TB was not able to quench the surface fluorescence completely, but left a certain amount of background fluorescence. Within unfractionated leucocyte pools, the lymphocyte population which is able to bind but not phagocytose bacteria, can serve as a control for the quenching efficiency of TB. The quenching is illustrated in Figs. $1 \mathrm{~b}$, $\mathrm{c}$ and $\mathrm{d}$, where neutrophils incubated with non-opsonised $S$. mutans at $37^{\circ} \mathrm{C}$ for $60 \mathrm{~min}$ showed weak binding with $60 \%$ of fluorescence-positive cells and MFI of 100 before quenching (Fig. 1b) and with $30 \%$ of fluorescencepositive cells and MFI of 65 after quenching (Fig. 1c). On the other hand, neutrophils incubated with $S$. mutans opsonised with IP $5 \mathrm{mg} / \mathrm{ml}$ showed efficient phagocytosis with $98 \%$ of positive cells and MFI of 720 after quenching (Fig. 1d). From the two parameters, MFI and the percentage of fluorescencepositive phagocytes, the following quantities were 
derived: (1) Relative amount of phagocytosed bacteria, $\mathrm{MFI}_{\mathrm{i}}=(\mathrm{MFI}+\mathrm{TB})$; (2) relative amount of bacteria bound on cell surface, $\mathrm{MFI}_{\mathrm{s}}=\mathrm{MFI}-(\mathrm{MFI}+\mathrm{TB})$; (3) phagocytosis efficiency of the particular cell population, $\quad \mathrm{PHE}=(\%+\mathrm{TB}) \times \mathrm{MFI}_{i}$; (4) percentage of fluorescence-positive cells bearing target only on surface, $\%_{\mathrm{s}}=[\%-(\%+\mathrm{TB})] / \% \times 100$ in these calculations, $\%=\%$ of fluorescence-positive cells without $\mathrm{TB} ;(\%+\mathrm{TB})=\%$ of fluorescence-positive cells with TB; MFI = Mean fluorescence intensity without TB; $(\mathrm{MFI}+\mathrm{TB})=$ Mean fluorescence intensity with TB.

Flow cytometry was performed with a Coulter Epics XL flow cytometer (Coulter, Miami, FL, USA) with an argon ion laser. The laser excitation wavelength was $488 \mathrm{~nm}$, and the emitted light was collected through $550-\mathrm{nm}$ dichromic and 525 bandpass filters. The fluorescence of $c .5000$ cells was measured by using logarithmic amplification.

\section{Myeloperoxidase release}

Myeloperoxidase (MPO) release was evaluated by measuring the luminol-enhanced chemiluminescence (CL) emission of leucocytes. The assays were performed in $0.3 \mathrm{ml}$ of gel-HBSS containing leucocytes $\left(3.0 \times 10^{5}\right)$, bacteria $\left(c .1 .5 \times 10^{7}\right)$ and $0.5 \mathrm{~mm}$ luminol (5-amino-2,3 -dihydro-1,4-phthalazinedione, Sigma). The bacteria were either non-opsonised or opsonised with IP or CP. To test the effect of FITC-labelling on the $\mathrm{CL}$ response of phagocytes, some experiments were also performed with labelled bacteria (Fig. 4). The reaction mixtures were incubated at $37^{\circ} \mathrm{C}$ and the $\mathrm{CL}$ response was measured with BioOrbit 1251 Luminometer (BioOrbit, Turku, Finland) [23]. All CL assays were done in duplicate and repeated with leucocytes from six healthy donors. The same blood samples were used for flow cytometry measurements. The results are presented as peak CL values. Integral values of CL (0$60 \mathrm{~min}$ ) did not appear to yield additional useful information.

\section{Killing assays}

Killing of bacteria was determined only with nonopsonised and IP-opsonised bacteria, because CP did not have any effect on either phagocytosis or leucocyte activation. The assay mixtures contained, in $0.5 \mathrm{ml}$ of gel-HBSS, non-opsonised or IP-opsonised $S$. mutans NCTC 10449 harbouring plasmid pCSS945 containing the luc gene of firefly [24] $\left(3.0 \times 10^{7}\right)$ and leucocytes $\left(3 \times 10^{6}\right)$. Samples were withdrawn after incubation for $60 \mathrm{~min}$ at $37^{\circ} \mathrm{C}$ and the leucocytes were disrupted by adding 10 volumes of ice-cold sterile water followed by ultrasonication for $10 \mathrm{~s} ; 100-\mu 1$ samples were transferred to a luminometer cuvette. D-Luciferin (100 $\mu 1,0.5 \mathrm{mM}, \mathrm{pH} 6.0)$ was added and the bioluminescence measured at $37^{\circ} \mathrm{C}$ with a BioOrbit 1251 luminometer. The assay was done in duplicate and repeated three times. To confirm that the decrease in luminescence seen was true killing and not due to bacteriostatic action, similar experiments were performed also on solid media. After incubation for $60 \mathrm{~min}$, the leucocytes were disrupted as above and diluted samples were plated on BHI or Mitis-salivarius (MS; Difco) agar plates and cfu were determined. To exclude the effects of incubation, ice-cold water and sonication on the viability and light production of the bacteria, the samples were compared with control samples which were incubated and handled without leucocytes.

\section{Results}

\section{Phagocytosis}

Neutrophils in the presence of opsonised S. mutans accumulated fluorescence on the surface and inside the cells during incubation for $60 \mathrm{~min}$ at $37^{\circ} \mathrm{C}$ (Fig. 2a, c). Binding and phagocytosis reached a stationary level after $45 \mathrm{~min}$ of incubation. All neutrophils had at least bound opsonised bacteria on their surface after incubation for $5 \mathrm{~min}$ and after $15 \mathrm{~min}$ all neutrophils incubated with the opsonised bacteria also contained internalised bacteria (Fig. 2b,d). On the contrary, there was only minor accumulation of fluorescence when neutrophils were incubated with non-opsonised bacteria, or with bacteria treated with CP (Fig. 2a, c). About half of the neutrophils in these experiments contained intracellular fluorescence after incubation for $60 \mathrm{~min}$ (Fig. 2b), while c. $40 \%$ of the fluorescent cells had non-opsonised or CP-opsonised bacteria bound only to the cell surface (Fig. 2d). IP contained opsonins which, dose-dependently, increased binding and phagocytosis of these bacteria (Fig. 3). Analogous results were obtained also from experiments with $S$. sobrinus (data not shown). Monocytes and eosinophils showed similar kinetics of phagocytosis to neutrophils (data not shown) and their phagocytic activities, with lymphocytes as controls, are compared in Table 1. It should be noted that both the percentage of lymphocytes containing intracellular fluorescence and the mean fluorescence intensity of lymphocytes, which did not phagocytose, were roughly the same as those of phagocytes in the presence of non-opsonised bacteria after incubation for $60 \mathrm{~min}$ (Table 1). However, both parameters increased in phagocytes, but not in lymphocytes, during the incubation (data not shown), suggesting that neutrophils, monocytes and eosinophils phagocytose non-opsonised bacteria weakly. Neutrophils performed $96 \%$ of the total phagocytosis of opsonised bacteria in the phagocyte population (Table 1).

\section{Myeloperoxidase release}

Fig. 4 illustrates the kinetics of luminol-amplified chemiluminescence of phagocytes. The addition of phagocytes to the reaction mixture in the absence of bacteria generated a rapid CL burst with the peak at 

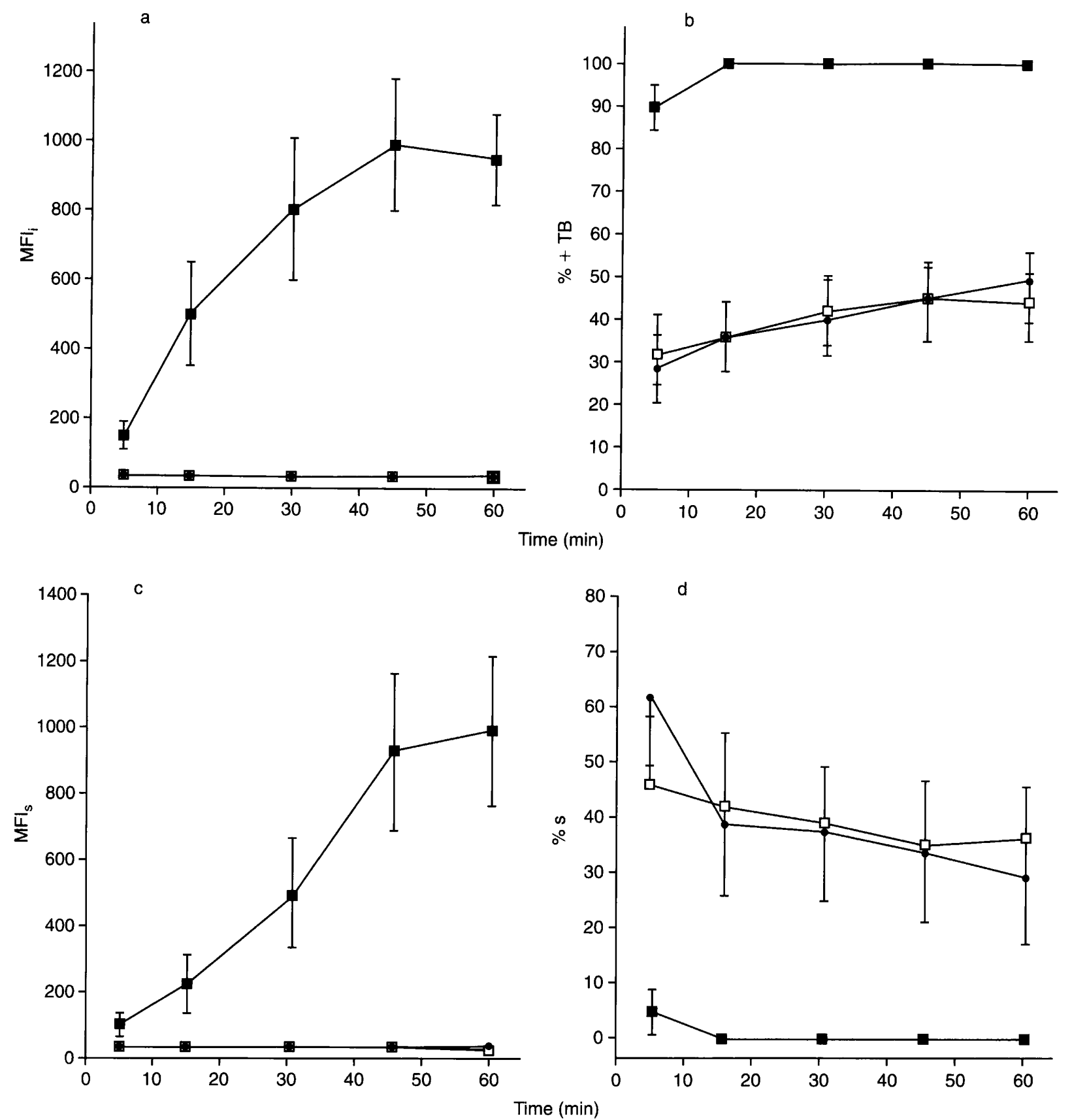

Fig. 2. Kinetics of phagocytosis of $S$. mutans. The non-opsonised $(\bullet)$ or immune product (IP, $5 \mathrm{mg} / \mathrm{ml}$; $\mathbf{\square}$ )- or control product $(\mathrm{CP}, 5 \mathrm{mg} / \mathrm{ml} ; \square)$ - opsonised FITC-labelled bacteria were incubated with leucocytes for 60 min at $37^{\circ} \mathrm{C}$. Samples were taken at indicated time intervals and the relative mean fluorescence intensity and the proportion of neutrophils containing phagocytosed particles were measured (mean and SE, $n=6$ ). (a) $\mathrm{MFI}_{\mathrm{i}}$ (relative amount of phagocytosed bacteria), (b) $\%+\mathrm{TB}$ (\% of cells with ingested bacteria), (c) $\mathrm{MFI}_{\mathrm{S}}$ (relative amount of bacteria bound on the cell surface) and (d) $\%_{s}$ (\% of fluorescent cells bearing bacteria only on the surface).

$5 \mathrm{~min}$. The CL burst was also observed in the presence of non-opsonised bacteria. On the other hand, when opsonised bacteria were present, another peak appeared after $c .30 \mathrm{~min}$. It can be concluded that the first peak represents extracellular events (release of MPO, superoxide anion and $\mathrm{H}_{2} \mathrm{O}_{2}$ from the cells) when phagocytes react with the surface of luminometer vials and with each other, while the second peak represents the activity of MPO released from primary granules into phagolysosomes. The effects of opsonisation both on the MPO activity (Fig. 5) and on the amount of ingested bacteria (Fig. 3) are essentially the same. This suggests that the amount of MPO released from primary granules into phagolysosomes is closely related to the amount of ingested bacteria. Moreover, because the labelling of bacteria by FITC did not essentially affect the CL emission (Fig. 4) it can be concluded that FITC labelling does not influence the ingestion of bacteria.

\section{Killing assays}

The viability of bacteria was assayed after incubation for $60 \mathrm{~min}$, when the ingestion of mutans streptococci 


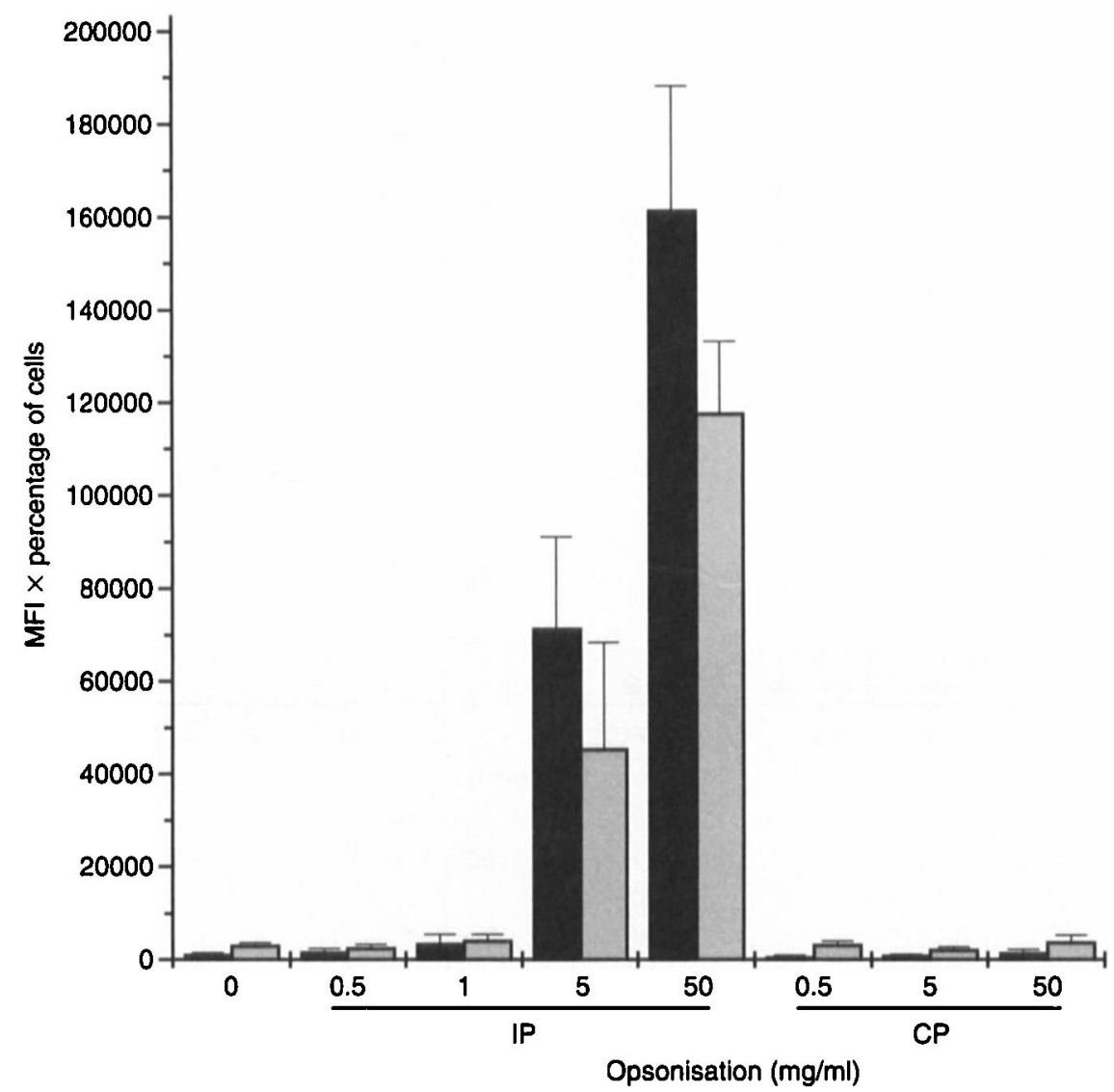

Fig. 3. Dose-dependency of $S$. mutans opsonisation on phagocytosis. The bacteria were opsonised with different concentrations of IP or $\mathrm{CP}$ and incubated with leucocytes for $60 \mathrm{~min}$ at $37^{\circ} \mathrm{C}$ (mean and $\mathrm{SE}, \mathrm{n}=4$ ); $\boldsymbol{\square}$, inside leucocytes; , on surface of phagocytes.

Table 1. Phagocytosis of FITC-labelled $S$. mutans by human leucocytes; the relative proportions of neutrophils, monocytes, eosinophils and lymphocytes were measured by flow cytometry (percent of cells counted)*

\begin{tabular}{|c|c|c|c|c|c|c|c|c|}
\hline \multirow[b]{2}{*}{ Cell type } & \multirow{2}{*}{$\begin{array}{c}\text { Mean (SD) } \\
\text { percentage } \\
\text { of cells counted }\end{array}$} & \multirow[b]{2}{*}{ Opsonisation } & \multicolumn{2}{|c|}{ Before quenching } & \multicolumn{2}{|c|}{ After quenching } & \multirow{2}{*}{$\begin{array}{l}\text { Counted } \\
\text { cells } \\
(\%) \times \text { PHE }\end{array}$} & \multirow{2}{*}{$\begin{array}{c}\text { Percentage } \\
\text { of total } \\
\text { phagocytosi }\end{array}$} \\
\hline & & & $\begin{array}{l}\text { Fluorescent } \\
\text { cells (\%) (SD) }\end{array}$ & $\begin{array}{l}\text { MFI } \\
\text { (SD) }\end{array}$ & $\begin{array}{l}\text { Fluorescent } \\
\text { cells }(\%)\end{array}$ & $\begin{array}{l}\mathrm{MFI}_{\mathrm{i}} \\
(\mathrm{SD})\end{array}$ & & \\
\hline \multirow[t]{2}{*}{ Neutrophils } & $60(6)$ & - & $60(6)$ & $70(26)$ & $22(9)$ & $56(26)$ & & \\
\hline & & + & $100(0)$ & $1170(470)$ & $98(2)$ & $720(230)$ & 4230000 & 96 \\
\hline \multirow[t]{2}{*}{ Monocytes } & $11(3)$ & - & $67(5)$ & $57(5)$ & $49(13)$ & $30(5)$ & & \\
\hline & & + & $95(2)$ & $300(50)$ & $87(6)$ & $170(3)$ & 160000 & 3.6 \\
\hline \multirow[t]{2}{*}{ Eosinophils } & $1.5(1)$ & - & $60(6)$ & $75(5)$ & $26(11)$ & 53 (17) & & \\
\hline & & + & 89 (14) & $320(120)$ & $79(8)$ & $140(50)$ & 20000 & 0.5 \\
\hline \multirow[t]{2}{*}{ Lymphocytes } & $28(8)$ & - & $49(7)$ & $61(2)$ & $17(5)$ & $29(5)$ & & \\
\hline & & + & $66(3)$ & $80(10)$ & $36(6)$ & 40 (10) & 40000 & $\S$ \\
\hline
\end{tabular}

${ }^{*}$ In each leucocyte population the proportions of fluorescent cells (\%) and mean fluorescence intensity (MFI) of the cells after incubation $\left(60 \mathrm{~min}, 37^{\circ} \mathrm{C}\right)$ with immune product $(5 \mathrm{mg} / \mathrm{ml})$ and opsonised or non-opsonised bacteria were determined (mean, $\left.\mathrm{SD}, \mathrm{n}=4\right)$. Measurements were made before and after quenching extracellular fluorscence with trypan blue. The phagocytosis efficiency of each cell population was counted as following: cells counted (\%) $\times$ PHE.

PHE, cells fluorescing $(\%) \times$ MFI after quenching with trypan blue.

$\S$ As lymphocytes are not able to phagocytose their 'phagocytic activity' was not included.

by phagocytes had ceased. Almost $90 \%$ of nonopsonised bacteria were alive in both bioluminescence and plate count assays (Fig. 6). There was a trend towards fewer bacteria being alive after phagocytosis and opsonisation (Fig. 6) but the reduction did not reach statistical significance (Student's $t$-test).

\section{Discussion}

In the absence of opsonins, human phagocytes are inefficient in destroying mutans streptococci $[25,26]$ as was shown in the present study. Bovine whey from hyperimmunised cows augmented markedly the capa- 


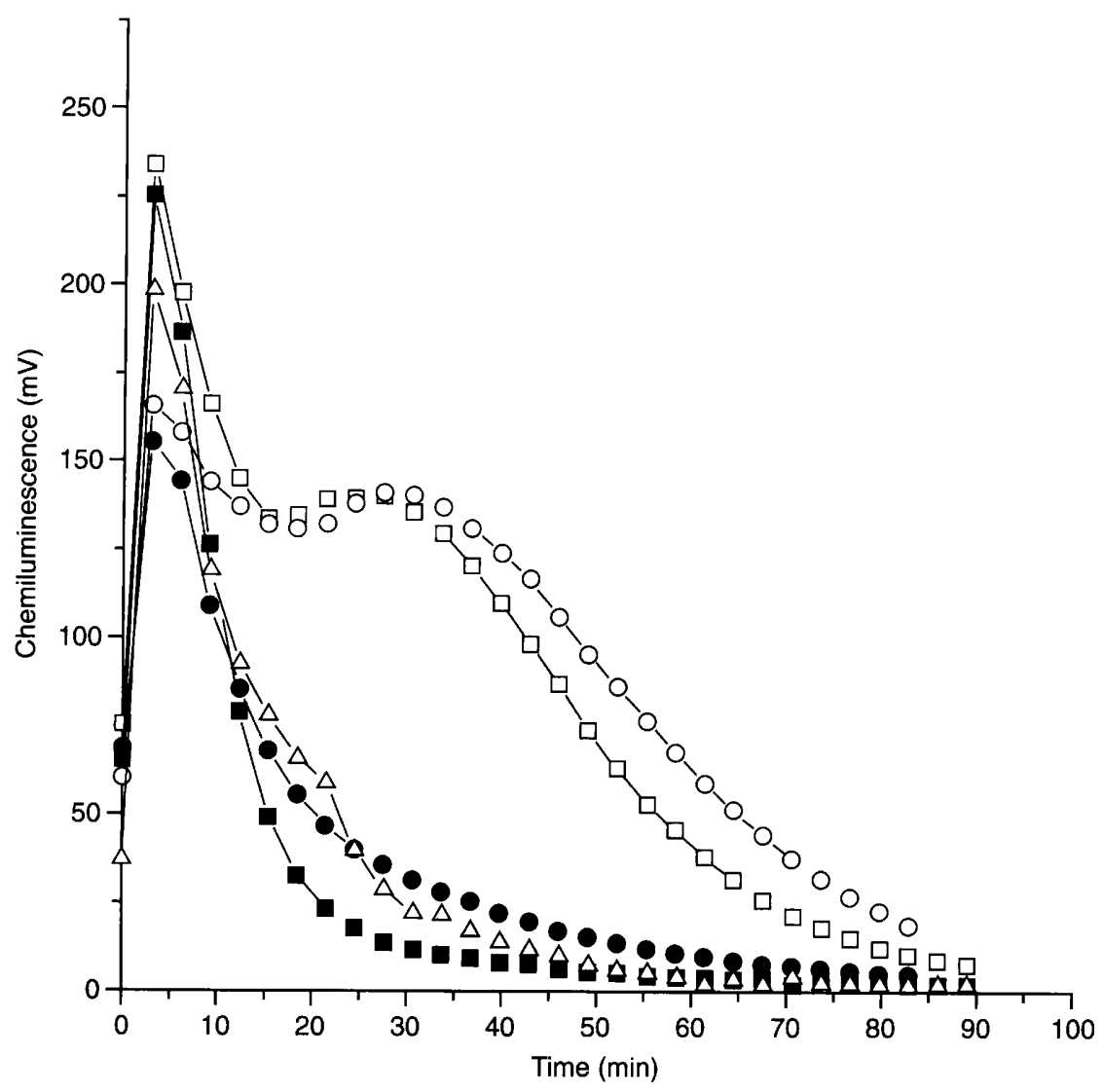

Fig. 4. MPO release. The bacteria were either non-opsonised (NOPS) or opsonised with immune product $5 \mathrm{mg} / \mathrm{ml}$ (OPS) and some of the bacteria were further labelled with FITC. The bacteria were then incubated with leucocytes obtained from one donor and the luminol-enhanced CL $(\mathrm{mV})$ was measured with a luminometer for 90 min. The figure shows one representative experiment out of six. $\mathbf{0}$, NOPS; $\square$, OPS; 9 , NOPS + FITC; O, OPS + FITC; $\triangle$, background.

city of the phagocytes to bind and ingest these pathogenic bacteria. Neutrophils were found to ingest the highest amounts of opsonised bacteria and, due to their abundance in peripheral blood, they comprised $96 \%$ of the total phagocytic activity in these assays.

Opsonisation of mutans streptococci by normal human serum or by polyclonal specific antibodies from rodents increase the leucocyte activity against these bacteria $[26,27]$. Concentrations of $\geqslant 5 \mathrm{mg} / \mathrm{ml}$ of the whey product were needed to induce the phagocytic activity in the present study. However, c. $50 \%$ of the product is composed of immunoglobulins and not all these immunoglobulins are specific for streptococci; thus, the concentration of specific opsonins is much lower. In the bovine whey preparations, $\mathrm{IgG}_{1}$ comprises $83 \%$ of total immunoglobulin fraction, $\operatorname{IgM}(10.7 \%), \mathrm{IgG}_{2}$ $(3.7 \%)$ and $\operatorname{IgA}(2.8 \%)$ being less abundant [10]. Bovine IgGs and IgM enhance the phagocytic activity of bovine leucocytes by opsonising bacteria, but $\operatorname{IgA}$ lacks such an activity. Human colostrum affects human phagocytes - both inhibition [28] and activation [29] have been reported - and bovine whey proteins may inhibit the phagocytic activity of bovine leucocytes [12] but, to our knowledge, there are no reports about their effects on human leucocytes. However, passive immunisation regimens based on bovine colostrum are developed against many microbial diseases and, therefore, interactions between bovine whey proteins and human immune defence cells, e.g. leucocytes, are of interest. Thus, as the aim of the study was not just to examine the interactions of specific bovine immunoglobulins and human leucocytes, but also the general effects of bovine colostral whey protein preparations on the activity of human leucocytes, the specific immunoglobulins were not purified further. No difference was found between activities of non-treated and control whey-treated leucocytes, indicating that bovine whey proteins do not interfere with the phagocytic activity of human peripheral neutrophils. It has been suggested that the inhibitory activity of whey proteins towards bovine leucocytes is due to blocking the Fc-receptors on leucocyte surfaces [12]. It is possible that such factors are washed out during processing of whey proteins or that they do not bind with human Fcreceptors. However, the bovine immunoglobulins bound on bacterial surfaces were apparently recognised by human leucocytes, as the whey proteins from the colostrum of $S$. mutans $/ S$. sobrinus-immunised cows markedly increased the phagocytosis of mutans streptococci.

Although the chemiluminescence measurements showed high respiratory burst activities in leucocytes 


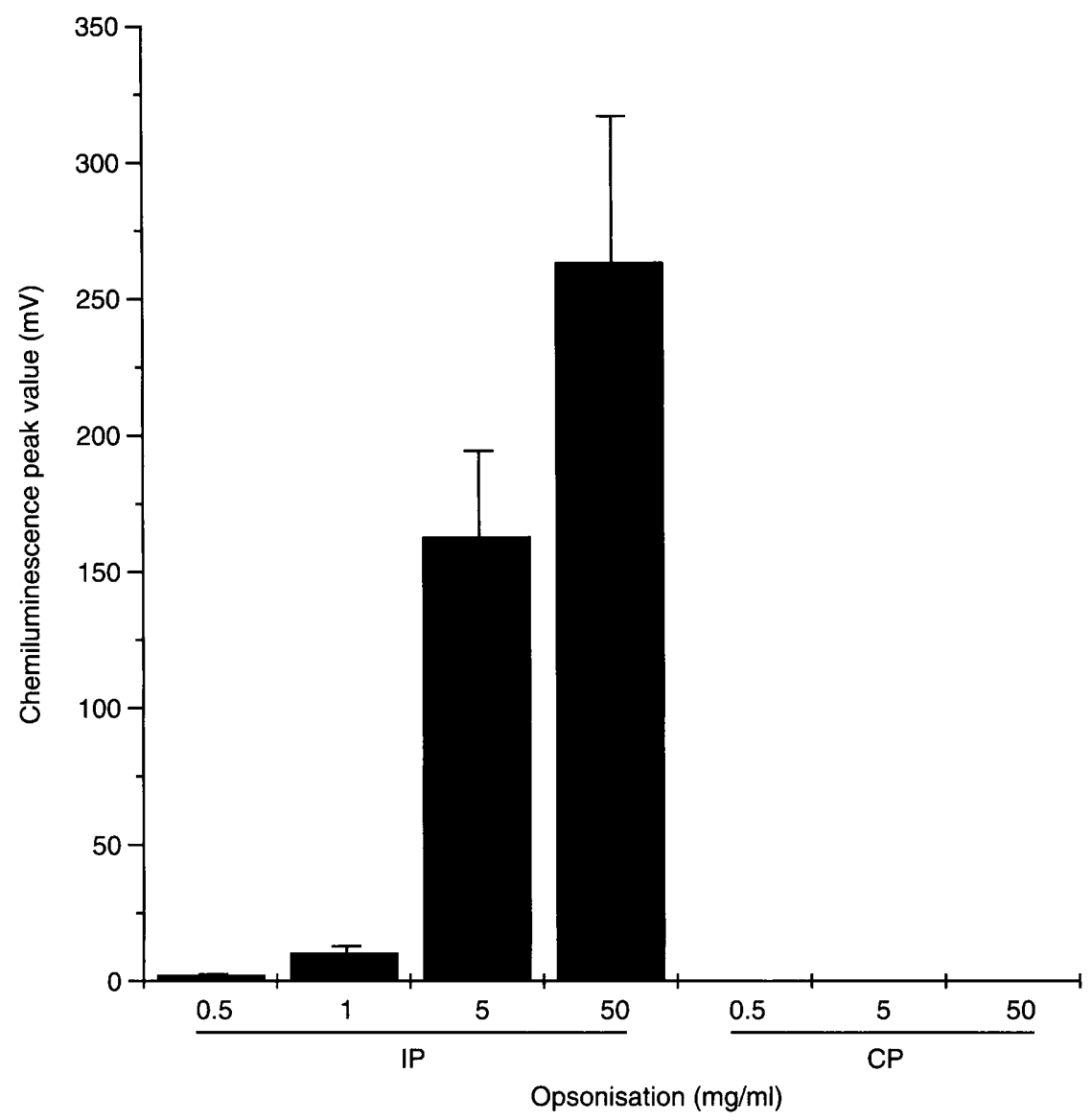

Fig. 5. Dose-dependency of $S$. mutans opsonisation on MPO release. The bacteria were opsonised with different concentrations of IP or $\mathrm{CP}$ and incubated with leucocytes for $60 \mathrm{~min}$ at $37^{\circ} \mathrm{C}$. The luminol enhanced $\mathrm{CL}$ was measured with a luminometer for $90 \mathrm{~min}$. Results are expressed as mean peak CL values of the second peak (see Fig. 4), which appeared c. 30 min. after the first peak (bar, SD; $\mathrm{n}=6$ ).

during the phagocytosis of opsonised bacteria, killing of the streptococci was rather inefficient. The respiratory burst activity of phagocytes produces superoxide anion radical by the NADPH oxidase complex on the plasma membrane. Superoxide radical is dismutated to $\mathrm{H}_{2} \mathrm{O}_{2}$, which serves as a substrate for MPO provided that this enzyme is released from primary granules [30]. The luminol CL has been shown to be nearly completely dependent on MPO both in neutrophils [31-33] and in monocytes [34,35] and, moreover, on the release of MPO from the granules [36-39]. Thus, luminol appears to be an excellent probe for the biochemical events preceding the oxygen-dependent killing. Recorded low killing rates seem to contradict the high respiratory burst activity, but the differences may be due to the killing assay protocol in which bacteria bound on the surface of the phagocytes or free bacteria were not removed before lysis of phagocytes. Therefore, ingested, surface-bound and free bacteria are all included in the viability assays, thus resulting in killing rates that are too low. Moreover, killing may have continued after incubation for $60 \mathrm{~min}$, because MPO activity was measurable for at least $90 \mathrm{~min}$, but reactive oxygen species formed in phagolysosome may also be ineffective in the killing of $S$. mutans. On the other hand, killing of the ingested bacteria is apparently less important in the oral cavity than elsewhere in the human body, as most leucocytes are removed from the mouth by swallowing, and with the swallowed leucocytes all ingested bacteria, live or dead, are also removed.

MPO, derived from PMNLs, as well as specific antibodies, inhibit the adherence of $S$. mutans on saliva-coated surfaces [40-42] and leucocytes can even detach adherent oral bacteria from saliva-coated hydroxyapatite [43]. Even though the activation of leucocytes is not needed to prevent re-colonisation by indigenous bacteria in human adults [18], it may be an important mechanism in modifying the colonisation of bacteria on erupting teeth. In vivo, most of the leucocytes are eventually removed from the oral cavity by swallowing, and thus, detachment and phagocytosis are sufficient to remove bacteria and prevent their colonisation. Thus, by effectively opsonising mutans streptococci as they enter the oral cavity during early childhood, their establishment could be prevented. As suggested by this study, bovine immune whey may offer an effective and economical tool for this purpose. 


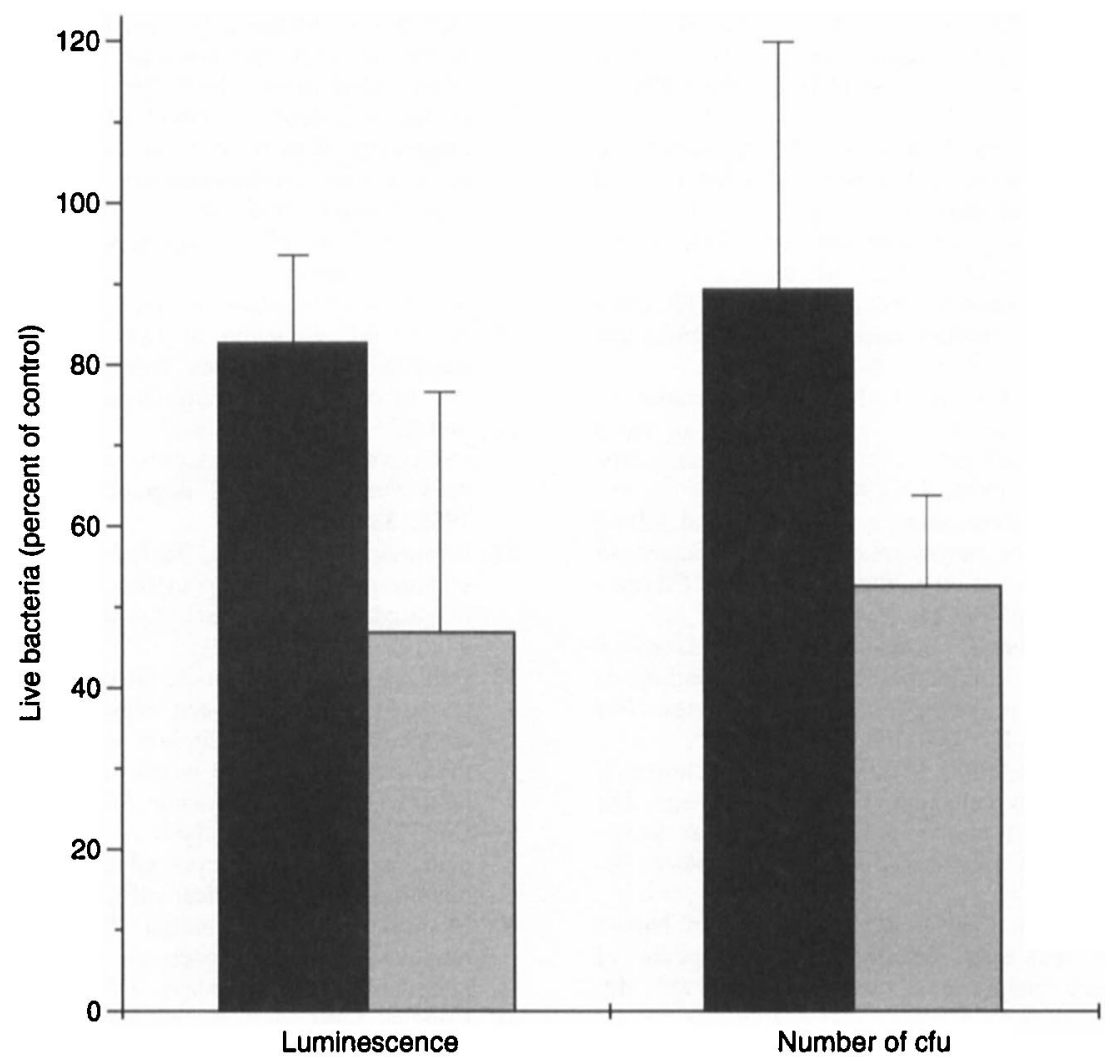

Fig. 6. The killing of opsonised ( $\square$ ) and non-opsonised (⿴囗十) S. mutans by human leucocytes. The killing was measured as a reduction of $\mathrm{cfu}$ on agar plates and also as a reduction in luminescence of bioluminescent $S$. mutans strain after incubation of the bacteria with leucocytes for $1 \mathrm{~h}$ at $37^{\circ} \mathrm{C}$ (mean; bar, SD).

This study was supported by the Academy of Finland and the Finnish Technology Development Centre (TEKES).

\section{References}

1. Loesche WJ. Role of Streptococcus mutans in human dental decay. Microbiol Rev 1986; 50: 353-380.

2. Krisher K, Cunningham MW. Myosin: a link between streptococci and heart. Science 1985; 227: 413-415.

3. Ma JK-C, Smith R, Lehner T. Use of monoclonal antibodies in local passive immunisation to prevent colonization of human teeth by Streptococcus mutans. Infect Immun 1987; 55: 1274-1278.

4. Ma JK-C, Lehner T, Stabila P, Fux CI, Hiatt A. Assembly of monoclonal antibodies with IgGl and IgA heavy chain domains in transgenic tobacco plants. Eur J Immunol 1994; 24: $131-138$.

5. Hamada S, Horikoshi $\mathrm{T}$, Minami $\mathrm{T}$ et al. Oral passive immunization against dental caries in rats by use of hen egg yolk antibodies specific for cell-associated glukosyltransferase of Streptococcus mutans. Infect Immun 1991; 59: 4161-4167.

6. Otake S, Nishihara Y, Makimura M et al. Protection of rats against dental caries by passive immunisation with hen-eggyolk antibody (IgY). J Dent Res 1991; 70: 162-166.

7. Michalek SM, Gregory RL, Harmon CC et al. Protection of gnotobiotic rats against dental caries by passive immunisation with bovine milk antibodies to Streptococcus mutans. Infect Immun 1987; 55: 2341-2347.

8. Filler SJ, Gregory RL, Michalek SM, Katz J, McGhee JR. Effect of immune bovine milk on Streptococcus mutans in human dental plaque. Arch Oral Biol 1991; 36: 41-47.

9. Korhonen $\mathrm{H}$. Colostrum immunoglobulins and the complement system - potential ingredients of functional foods. In: IDF, Dairy Foods in Health, Proceedings of IDF Nutrition Week, Wellington, New Zealand 1998 (in press).

10. Loimaranta V, Tenovuo J, Virtanen $\mathrm{S}$ et al. Generation of bovine immune colostrum against Streptococcus mutans and
Streptococcus sobrinus and its effect on glucose uptake and extracellular polysaccharide formation by mutans streptococci. Vaccine 1997; 15: 1261-1268.

11. Loimaranta V, Carlén A, Olsson J, Tenovuo J, Syväoja E-L Korhonen H. Concentrated bovine colostral whey proteins from Streptococcus mutans/Strep. sobrinus immunized cows inhibit the adherence of Strep. mutans and promote the aggregation of mutans streptococci. J Dairy Res 1998; 65: 599-607.

12. Targowski SP, Niemialtowski M. Inhibition of lacteal leukocyte phagocytosis by colostrum, nonlactating secretion, and mastitic milk. Am J Vet Res 1986; 47: 1940-1945.

13. Jungi TW, Peterhans E, Pfister H, Fey $H$. The interaction of ruminant IgG with receptor type II for IgG on human phagocytes. Immunology 1989; 66: 143-148.

14. Scully C. Phagocytic and killing activity of human blood, gingival crevicular, and salivary polymorphonuclear leukocytes for oral streptococci. J Dent Res 1982; 61: 636-639.

15. Scully $\mathrm{C}$, Wilkinson PC. Inflammatory polymorphonuclear neutrophil leukocytes; orientation, chemotactic, locomotor and phagocytic capabilities of neutrophils from the human gingival crevice. J Clin Lab Immunol 1985; 17: 69-73.

16. Fumarulo R, Giordano D, Laforgia A, Larocca A, Quarto $M$. Salivary effects on polymorphonuclear leukocyte functions. Oral Microbiol Immunol 1993; 8: 125-127.

17. Caufield PW, Cutter GR, Dasanayake AP. Initial acquisition of mutans streptococci by infants: evidence for a discrete window of infectivity. $J$ Dent Res 1993; 72: 37-45.

18. Ma JK-C, Hunjan $M$, Smith $R$, Kelly $C$, Lehner T. An investigation into the mechanism of protection by local passive immunization with monoclonal antibodies against Streptococcus mutans. Infect Immun 1990; 58: 3407-3414.

19. De Grooth BG, Terstappen LW, Puppels GJ, Greve J. Lightscattering polarization measurements as a new parameter in flow cytometry. Cytometry 1987; 8: 539-544.

20. Hed J, Halden G, Johansson SGO, Larsson P. The use of fluorescence quenching in flow cytofluorometry to measure the attachment and ingestion phases in phagocytosis in peripheral blood without prior cell separation. J Immunol Methods 1987; 101: $119-125$. 
21. Boos H, Stoehr M, Sauter M, Mueller-Lantzsch M. Flow cytometric analysis of Epstein-Barr virus (EBV) latent membrane protein expression in EBV-infected Raji-cells. $J$ Gen Virol 1990; 71: 1811-1815.

22. Sveum RJ, Chused TM, Frank MM, Brown EJ. A quantitative fluorescent method for measurement of bacterial adherence and phagocytosis. J Immunol Methods 1986; 90: 257-264.

23. Lilius E-M, Waris M. A very sensitive and rapid chemiluminescence method for the measurement of phagocytosis. In: Kricka LJ, Stanley PE, Thorpe GHG, Whitehead TP (eds) Analytical applications of bioluminescence and chemiluminescence. Orlando, Academic Press. 1984: 401-404.

24. Loimaranta V, Tenovuo J, Koivisto L, Karp M. Generation of bioluminescent Streptococcus mutans and its usage in rapid analysis of the efficacy of antimicrobial compounds. Antimicrob Agents Chemother 1998; 42: 1906-1910.

25. Scully CM, Lehner T. Opsonization, phagocytosis and killing of Streptococcus mutans by polymorphonuclear leukocytes, in relation to dental caries in the rhesus monkey (Macaca mulatta). Arch Oral Biol 1979; 24: 307-312.

26. van Raamsdonk M, de Soet JJ, Bosch-Tijhof CJ, de Graaff J. Effect of antibodies on chemiluminescence and on killing of Streptococcus sobrinus by polymorphonuclear leucocytes. Oral Microbiol Immunol 1996; 11: 254-258.

27. Passo SA, Tsai C-C, McArthur WP, Leifer C, Taichman T. Interaction of inflammatory cells and oral microorganisms. IX. The bactericidal effects of human polymorphonuclear leukocytes on isolated plaque microorganisms. J Periodont Res 1980; 15: 470-482.

28. Pickering LK, Cleary TG, Caprioli RM. Inhibition of human polymorpho-nuclear leukocyte function by components of human colostrum and mature milk. Infect Immun 1983; 40: $8-15$.

29. Straussberg R, Sirota L, Hart J, Amir Y, Djaldetti M, Bessler H. Phagocytosis-promoting factor in human colostrum. Biol Neonate 1995 68: 15-18.

30. Klebanoff SJ. Oxygen metabolites from phagocytes. In: Gallin JL, Goldstein IM, Snyderman R (eds) Inflammation: basic principles and clinical correlates, 2nd edn. New York, Raven Press. 1992: 541-588.

31. Cohen MS, Shirley PS, DeChatelet LR. Further evaluation of luminol-enhanced luminescence in the diagnosis of disorders of leukocyte oxidative metabolism: role of myeloperoxidase. Clin Chem 1983; 29: 513-515.
32. Dahlgren C, Stendahl O. Role of myeloperoxidase in luminoldependent chemiluminescence of polymorphonuclear leukocytes. Infect Immun 1983; 39: 736-741.

33. Gerber CE, Kuci S, Zipfel M, Niethammer D, Bruchelt G. Phagocytic activity and oxidative burst of granulocytes in persons with myeloperoxidase deficiency. Eur $J$ Clin Chem Clin Biochem 1996; 34: 901-908.

34. Seim S. Role of myeloperoxidase in the luminol-dependent chemiluminescence response of phagocytosing human monocytes. Acta Pathol Microbiol Immunol Scand C 1983; 91: 123-128.

35. Zeller JM, Caliendo J, Lint TF, Nelson DJ. Changes in respiratory burst activity during human monocyte differentiation in suspension culture. Inflammation 1988; 12: 585-595.

36. Stendahl O, Andersson T, Dahlgren C, Magnusson K-E. Defective chemiluminescence response in differentiated HL60 cells due to impaired degranulation. Biochim Biophys Acta 1986; 881: 430-436.

37. Edwards SW, Say JE, Taylor J, Hart CA. Myeloperoxidase secretion during phagocytosis: a case of a patient with impaired bactericidal activity. J Clin Lab Immunol 1988; 27: 97-102.

38. Dahlgren C, Johansson A, Orselius K. Difference in hydrogen peroxide release between human neutrophils and neutrophil cytoplasts following calcium ionophore activation. A role of the subcellular granule in activation of the NADPH-oxidase in human neutrophils? Biochim Biophys Acta 1989; 1010: 41-48.

39. Del Principe D, Menichelli A, Di Giulio S et al. Stimulated platelets release factor(s) affecting the in vitro response of human polymorphonuclear cells. J Leukoc Biol 1990; 48: 7-14.

40. Miyasaki KT, de Camargo PM, Wolinsky LE. Differential modulation of adherence of oral streptococci by human neutrophil myeloperoxidase. $J$ Dent Res 1988; 67: 1300-1306.

41. Douglas CWI, and Russel RRB. Effect of specific antisera upon Streptococcus mutans adherence to saliva coated hydroxyapatite. FEMS Microbiol Lett 1984; 25: 211-214.

42. Hajishengallis G, Nikolova E, Russell MW. Inhibition of Streptococcus mutans adherence to saliva-coated hydroxyapatite by human secretory immunoglobulin A (s-IgA) antibodies to cell surface protein antigen I/II: reversal by IgA protease cleavage. Infect Immun 1992; 60: 5057-5064.

43. Erard J-C, Miyasaki KT, Wolinsky LE. Detachment of ora bacteria from saliva-coated hydroxyapatite by human polymorphonuclear leukocytes. $J$ Periodontol 1989; 60: 211-216. 